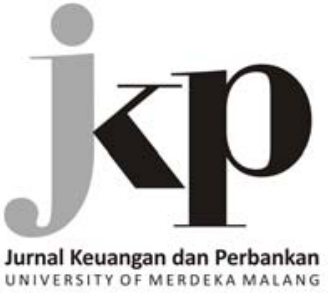

Article history:

Received: 2018-11-19

Revised: 2019-01-24

Accepted: 2019-03-05

Keywords:

Dividend payout; External factor; Indonesian banks; Internal factor; Stock price

JEL Classification: C33, E44, G21

Kata kunci:

Pembayaran dividen; Faktor eksternal; Bank di Indonesia; Faktor internal; Harga saham

$\square$ Corresponding Author:

Tribella Kembaren:

Tel. +6281 28100824

E-mail: tribella_k@yahoo,com

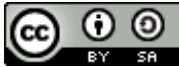

This is an open access article under the CC-BY-SA license

\section{Dividend payout, internal and other external factors, and its impact on stock price}

\author{
Tribella Kembaren, Noer Azam Achsani, Tb Nur Ahmad Maulana
}

Business School, Institut Pertanian Bogor

Jl. Pajajaran, Bogor 16151, Indonesia

\begin{abstract}
This study focuses on the effect of dividend payouts, internal and external factors on stock prices of corporate banking sub-sector. Based on core capital, banking companies in Indonesia are categorized into 4 BUKU (Commercial Bank Based on Business Activities). The findings of this study show that BUKU 4 (its core capital >= IDR. 30 billion) provides annual dividend payouts. Its dividend per share, dividend yield, and dividend payout ratio are higher than BUKU bank group 1, 2, and 3. This study also analyzes the effect of dividend payout, Net Interest Margin (NIM), Non-Performing Loan (NPL), inflation rate, interest rate, and Rupiah exchange rate (REER) on the stock prices of 31 banking companies indexed in IDX from annual data over the period of 2013 to 2017. Dividend payout and NIM have a positive and significant effect on stock prices. Panel data regression analysis found that the interest rate has a negative significant effect on stock prices. Meanwhile, the OLS regression test (dummy variable) found that NPL has a negative significant effect on stock prices.
\end{abstract}

\section{Abstrak}

Tulisan ini merupakan hasil penelitian untuk melihat dampak pembayaran dividen, faktor internal dan faktor eksternal lainnya terhadap harga saham subsektor perbankan. Perusahaan perbankan di Indonesia dikelompokkan menjadi 4 kelompok BUKU (Bank Umum berdasarkan Kegiatan Usaha) berdasarkan modal intinya. Penelitian ini menemukan bahwa seluruh bank pada BUKU 4 (modal inti >= 30 triliun rupiah) melakukan pembayaran dividen setiap tahun. Jumlah dividen per lembar saham, dividend yield dan Dividend Payout Ratio (DPR) pada bank di kelompok BUKU 4 lebih tinggi dari bank di kelompok BUKU 1,2 dan 3. Penelitian ini juga menganalisis dampak pembayaran dividen, Net Interest Margin (NIM), Non Performing Loan (NPL), tingkat inflasi, tingkat suku bunga dan nilai tukar rupiah (REER) terhadap harga saham 31 perusahaan perbankan yang terdaftar di BEI menggunakan regresi data panel dan regresi OLS (dummy variabel) dari data tahunan dari periode 2013-2017. Pembayaran dividen dan NIM memiliki pengaruh positifyang signifikan terhadap harga saham. Hasil regresi data panel menemukan tingkat suku bunga memiliki pengaruh negatif yang signifikan terhadap harga saham dan regresi OLS (dummy variable) menemukan NPL memiliki pengaruh negatif yang signifikan terhadap harga saham.

How to Cite: Kembaren, T., Achsani, N. A., \& Maulana, T. N. A. (2019). Dividend payout, internal and other external factors, and its impact on stock price Jurnal Keuangan dan Perbankan, 23(2), 235-245. https://doi.org/ 10.26905/jkdp.v23i2.2520 


\section{Introduction}

Gaining profit is what investors aim at when buying stocks. This can be either capital gain or dividends. Based on a study by Clark-Murphy \& Soutar (2004) on some investors in Australia, financial information such as dividends and price-earnings ratio will influence investors' decisions when buying stocks. In fact, the banking sector in Indonesia has a significant role in economic growth. An empirical study reveals that credit allocation has a relatively significant positive effect on the regional economy, particularly at the provincial level (Otoritas Jasa Keuangan, 2015). A number of banks operating in Indonesia as of December 2016 are 116. Even though there has been a decrease in the number of banks in Indonesia, there has been an increase in the number of bank assets and an increase in funds regulated by banks. If compared to other sectors, this financial sector has the largest market capitalization, which is equal to IDR. 2,091 trillion, 30 percent of Composite Stock Price Index. The financial sector has higher returns than the other eight sectors. The dividend policy regulated by a company will not have an impact on its stock prices and capital costs (Miller \& Modigliani, 1961). Bird in the hand theory suggested that investors are confident that stock prices will decrease along with the increase in dividend payments due to decreased capital gains from retaining earnings compared to cash. from dividend payouts (Lintner, 1962; Gordon, 1963). Moreover, some studies have found that there is a relationship between dividends and stock prices. A study by Badruzaman \& Kusmayadia (2017) shows that dividend payout ratio has a significant effect on the stock prices indexed in LQ45 of Indonesia Stock Exchange. In a study by Hashemijoo, Ardekani, \& Younesi (2012), there is a significant negative relationship between the volatility of stock prices and company dividend policies. Meanwhile, in a study by Kurniasih (2011) on companies indexed in Indonesia Stock Exchange, companies that provide dividend payouts have a larger size, greater retained earnings, and higher profitability.

Based on figure 1, figure 2, figure 3 and figure 4 , there are movements of stock prices and the amount of dividends per share in a BUKU 4 namely BBCA (Bank Central Asia, Tbk), BBRI (Bank Rakyat Indonesia Tbk), BBNI (Bank Negara Indonesia Tbk) and BMRI (Bank Mandiri Tbk). Based on the graph, even though the number of dividend changes every year, there is a trend of increase in the number of dividends per share in four banks from 2012 to 2016. The stock prices of these four banks have increased for four years, even though price fluctuation comes off every year.

Stock prices and dividends have positive relationships with BBCA issuers. In figure 1, the dividends issued by the companies from 2012-2016 had annual growth. The increase in dividends was followed by an increase in the stock price of BBCA every year. However, it did not apply to BBRI, BBNI, and BMRI since the increase in dividends was not accompanied by the increase in stock prices. In Figure 2, the dividend of BBRI increased by IDR. 36.86 (12,5 percent) in 2015 . Yet, in the same year, the stock price went down by IDR (1.93 percent). For five years, BBRI has increased by 250 percent in dividends and 67.98 percent in stock prices. In 2015, the dividends of BBNI increased but the stock prices of BBNI declined. Whereas, in 2016 the stock prices of BBNI increased even though their dividends declined (figure 3). The total increase in dividends of BBNI for 5 years was 96.11percent and the increase in stock price was 46.67percent. In 2013, the stock price of BMRI had a slight decline (3.08 percent) while its dividends got an increase of 89.9 percent. 
Dividend payout, internal and other external factors, and its impact on stock price

Tribella Kembaren, Noer Azam Achsani, Tb Nur Ahmad Maulana

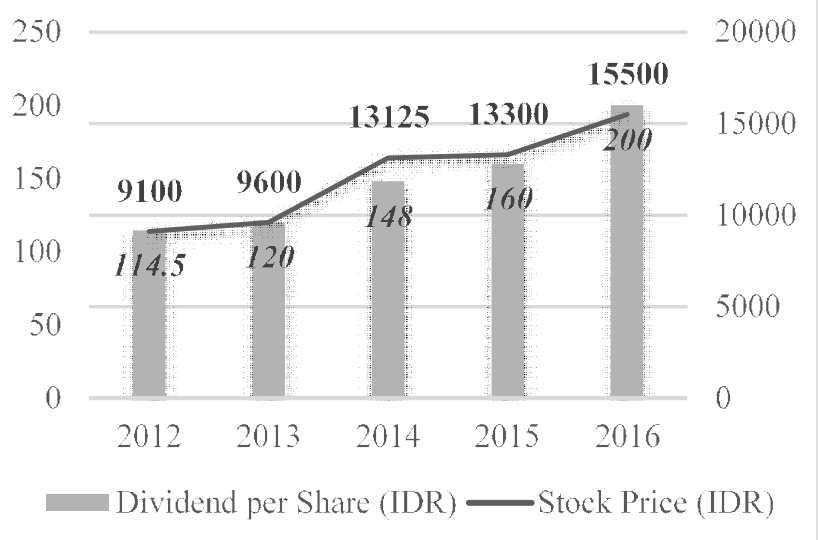

Figure 1. Stock price and dividend per share of BBCA Source: Indonesia Stock Exchange (2018)

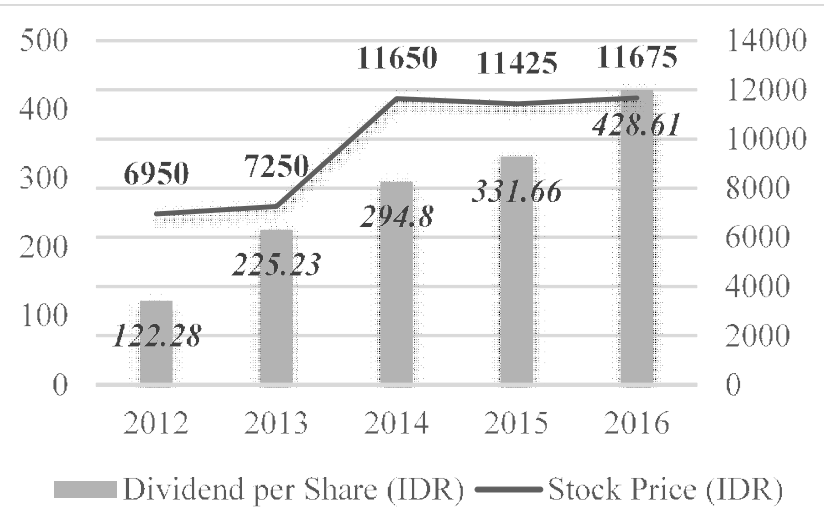

Figure 2. Stock price and dividend per share of BBRI Source: Indonesia Stock Exchange (2018)

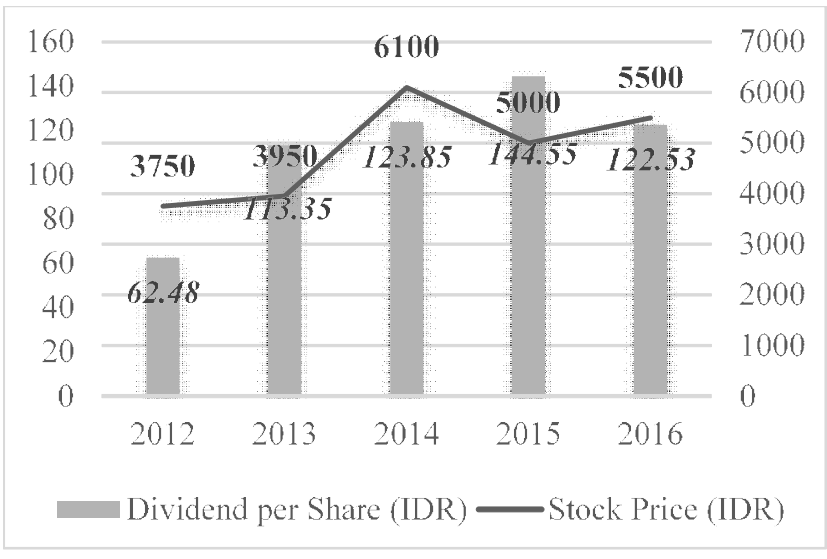

Figure 3. Stock price and dividend per share of BBNI Source: Indonesia Stock Exchange (2018)

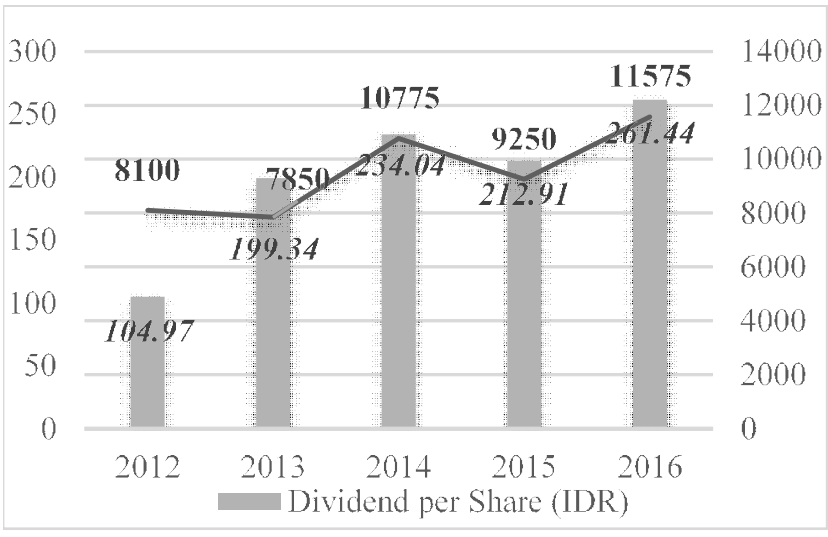

Figure 4. Stock price and dividend per share of BMRI Source: Indonesia Stock Exchange (2018)

Bank Indonesia (Central Bank) regulates business activities and office networks based on bank core capital in regulation No.14/26/PBI/2012. Financial Services Authority has regulation No.6/ PJOK.03/2016 concerning Business Activities and Office Networks Based on Core Capital Banks that make arrangements regarding the same thing. Based on the core capital, the bank is categorized as four BUKU, as follows: (1) BUKU 1 is a bank with a core capital < IDR 1 trillion. (2) BUKU 2 is a bank with a core capital of 1 trillion- < IDR 5 trillion. (3) BUKU 3 is a bank with a core capital of IDR 5 trillion- < IDR 30 trillion. (4) BUKU 4 is a bank with core capital $>=$ IDR 30 trillion.

Studies about dividends on banking sub-sector have not yet investigated differences in dividends among banks based on their core capitals even though according to Kurniasih (2011), companies that make dividend payouts are larger size ones. A study on US stocks by Hughen \& Beyer (2015) found that stock prices were affected by dollar trends. Stocks in the financial sector will show poor performance when the dollar value declines because when the dollar value decreases, inflation will rise. Whereas when the dollar decreases, the stock performance in the financial sector shows its best performance. Based on the results of this study, there is a relationship between the exchange rate and stock 
prices, particularly for stocks in the financial sector. Shivaani, Yadav, \& Jain (2015) conducted a study on 30 banking companies in India to examine the sensitivity of stocks toward three factors i.e., interest rates, inflation rates, and exchange rates. These three factors have a significant influence on the stock prices of banking companies in India.

Harahap \& Hairunnisah (2017) states that factors that significantly influence the stock price of banking companies listed on the stock exchange in 2010-2014 are NPL, NIM, and BOPO. This is similar to the result of a study by Wijayanti (2010) that NIM is a factor that significantly influences the banking stock prices on the Indonesia Stock Exchange. She also added that besides NIM, ROA, EPS, and PER are factors that have significantly influenced banking stock prices.

Based on the above formulation of problems, this study aims at analyzing dividend payment policies in the banking corporate sub-sectors on basis of capital core and investigating the relationship between dividends, internal factors and the external factors of the banking sub-sector with the stock price. The scope of the study is limited to annual financial report data in the form of Dividends per Share, Non-Performing Loans, and Net Interest Margin. Meanwhile, data obtained from Bank Indonesia are in the form of Rupiah Exchange Rate or REER, interest rate, and inflation rate. The stock prices of the banking sub-sector are indexed and published by the Indonesia Stock Exchange (IDX) during the period of 2013-2017.

Dividends are the distribution of company rewards or profits in which the amount of payouts is arranged by the directors and authorized by the shareholders. There are two types of dividends: cash dividends and stock dividends. Related to dividend policies, there are some types of dividend policies that companies commonly implement (Sutrisno, 2001), they are (1) stable dividend per-share policy, the company will distribute dividends with a fixed amount of earnings per year. (2) Constant dividend payout ratio, this policy uses a fixed percentage of company profits every year as dividends. (3) A compromise policy, dividends from companies to shareholders are arranged on the basis of a compromise approach. (4) Residual dividend policy, it considers investment opportunities that a company may perform. Regarding the theory of dividend policy, Miller \& Modigliani (1961) found that the dividend policy does not have an impact on stock prices or capital costs because it is irrelevant. Another theory is bird in the hand by Lintner (1962) \& Gordon (1963) suggesting that investors prefer dividends to profits from capital gains as it is more definite and more secure.

\section{Method, Data, and Analysis}

This study uses a descriptive approach, panel data regression, and OLS regression. The sampling method is purposive sampling with some criteria including the issuer of data had been enlisted as IPO (Initial Public Offering) before 2012 since Bank Indonesia regulation about core capital of the bank was enacted in 2012. The company operates until the end of the research period in 2017. The subjects of study are 31 companies, consisting of 2 Bank BUKU 2, 13 Bank BUKU 2, 12 Bank BUKU 3 and 4 Bank BUKU 4. This study uses secondary data which were obtained from the published annual financial report about banking sub-sector companies in the period of 2013-2017. Other data are stock prices in 2013-2017 from 31 research samples, inflation data (annual inflation rate), interest rates (annual interest rates) and exchange rates (value of Real Exchange Rate / REER).

The panel regression statistical tests use the following model:

$$
\begin{aligned}
Y_{i t}= & \beta_{0}+\beta_{1} D_{I V}+\beta_{2} N_{i t} L_{i t}+\beta_{3} N_{I M}+\beta_{4} I_{4} N L L A S I_{i t} \\
& +\beta_{5} \text { SUKU BUNGA }_{i t}+\beta_{6} \text { KURS }_{i t}+e
\end{aligned}
$$




\section{Dividend payout, internal and other external factors, and its impact on stock price}

Tribella Kembaren, Noer Azam Achsani, Tb Nur Ahmad Maulana

Where:

$\begin{array}{ll}\text { Y } & \text { : Stock price } \\ \text { DIV } & : \text { Dividend per Share } \\ \text { NPL } & : \text { Non-Performing Loan } \\ \text { NIM } & : \text { Net Interest Margin } \\ \text { INFLASI } & : \text { Inflation rate } \\ \text { SUKU BUNGA } & \text { : Interest rate } \\ \text { KURS } & \text { : Rupiah Exchange Rate (REER) } \\ \text { e } & : \text { Standard error }\end{array}$

This study also uses BUKU dummy variable with OLS regression method. The BUKU dummy variable has 4 categories, namely BUKU 1, BUKU 2, BUKU 3, BUKU 4 using the following formula:

Total category - $1=4-1=3$ dummy variables, so that there are 3 dummy variables with BUKU 4 as a comparison. The regression equation model with dummy variables is as follows:

$$
\begin{aligned}
Y_{i t}= & \beta_{0}+\beta_{1} D I V_{i t}+\beta_{2} N P L_{i t}+\beta_{3} N I M_{i t}+ \\
& \beta_{4} I N F L A S I_{i t}+\beta_{5} S U K U \text { BUNGA }+\beta_{6} K U R S_{i t} \\
& + \text { Dummy_BUKU1 }+ \text { Dummy_BUKU2 }+ \\
& \text { Dummy_BUKU3 }+e
\end{aligned}
$$

\section{Results}

This study found that the distributions of dividends were only performed by 19 companies (61.29 percent) in the banking corporate sub-sector with the distribution of dividend at least for once from 2013-2017. All companies in the bank BUKU 4 provide dividends every year for the last 5 years with an average amount of IDR. 222.18 per share. The highest dividend payout ratio is at 36.47 percent, referring to the bank BUKU 4. This group implements a policy of constant dividend payout ratio. The amount of dividends given by the company varies each year, but the payout ratio is almost constant every year. For example, BBRI issuers pay dividends for IDR. 225.23 in 2013, which is 30 percent of the payout ratio. In 2016 with the same payout ratio, the dividend accounted for IDR. 311.66. The BUKU 4 provides a higher dividend payout ratio than other bank BUKU groups in the annual average percentage of 28.88 percent. Some issuers in the bank BUKU 3 implement a constant dividend payout ratio. For instance, the issuer BBKP gives a constant 30 percent Dividend Payout Ratio. In the meantime, other issuers in the BUKU 3 implement stable dividend per share policy. As an illustration, the amount of dividends given by the company is constant every year. BJTM issuer gives a +/- dividend of IDR 40 every year even though the payout ratio changes 63.43 percent - 81.8 percent. Some companies that do not provide dividends apply residual dividend policies. For example, BSDW issuers did not make dividend payouts despite earning profits in 2014. It was due to the bank's efforts to increase capital through the retained earnings. (The financial report of Bank Indonesia, 2014).

The stock price of bank BUKU 2 increased by 36.03 percent, while the number of dividends fell to 12.79 percent. The stock price of bank BUKU 3 rose up to 46,46 percent, while the number of dividends fell to 66.02 percent. The stock price of bank BUKU 4 had a higher increase than other groups, which amounted to 130.37 percent. The amount of dividends payouts of bank BUKU 4 also increased. In fact, it had a higher amount of dividends than BUKU 2 and 3, which amounted to 70.92 percent. Dividends from banks fluctuate every year. The average growth of dividend payouts from banking corporate sub-sectors for the period 2013-2017 is 13.87 percent annually. The growth rate is higher than the annual inflation rate, which is in the percentage of 5.34 percent (Table 1).

Investors who buy shares from the banking corporate sub-sectors and earn dividends every year would earn money that has been protected from inflation if reinvested. Table 1 illustrates the highest dividend growth of bank BUKU 3, which is 16.28 percent. Bank BUKU 4 has an annual dividend growth of 14.67 percent. While the bank BUKU 2 has dividend growth of 8.86 percent.

The comparison of dividend yields among bank BUKU 1, 2, 3 and 4 is illustrated in Figure 5. 
BUKU 4 had a higher dividend yield than bank BUKU 2 and 3. In 2017, the bank BUKU 3 had a higher dividend yield because the stock price of the bank BUKU 4 increased more than bank BUKU 3 while the increase in dividends per share was not as large as the increase in the stock price. Based on these results, companies with larger core capital provide higher dividend yields.

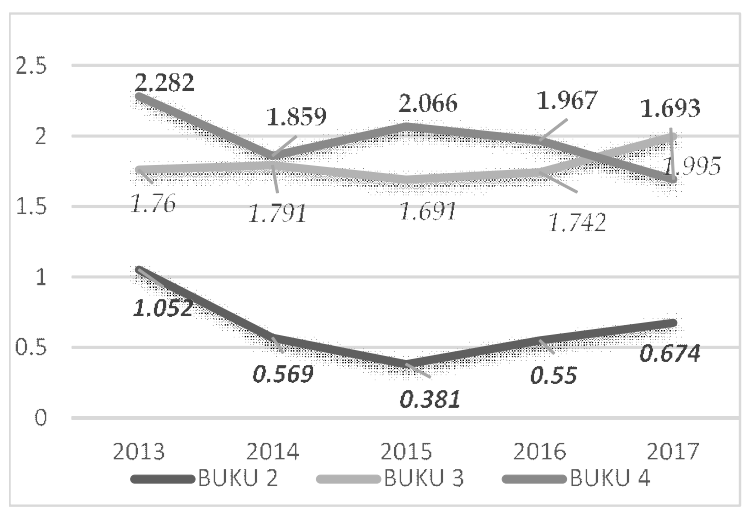

Figure 5. Dividend yields of bank BUKU 2, 3, and 4

The average dividend per share from banking corporate subsector from 2013 to 2017 had increased for 5 years, that was equal to 63.81 percent. The increase in the stock price for more than 5 years was 91.09 percent. Figure 6 illustrates the visual graphics of two-dimensional relationships between stock prices \& stock returns with dividends per share. There is a positive linear relationship between these two variables, meaning that if there is an in- crease in dividends, there will be an increase in stock prices and stock returns as well. NIM is an estimation of net income earned by a bank. This relationship between NIM and stock prices \& stock returns is illustrated in Figure 7. There is a positive linear relationship between these variables, meaning that if there is an increase in NIM, the stock price or stock return will increase as well.
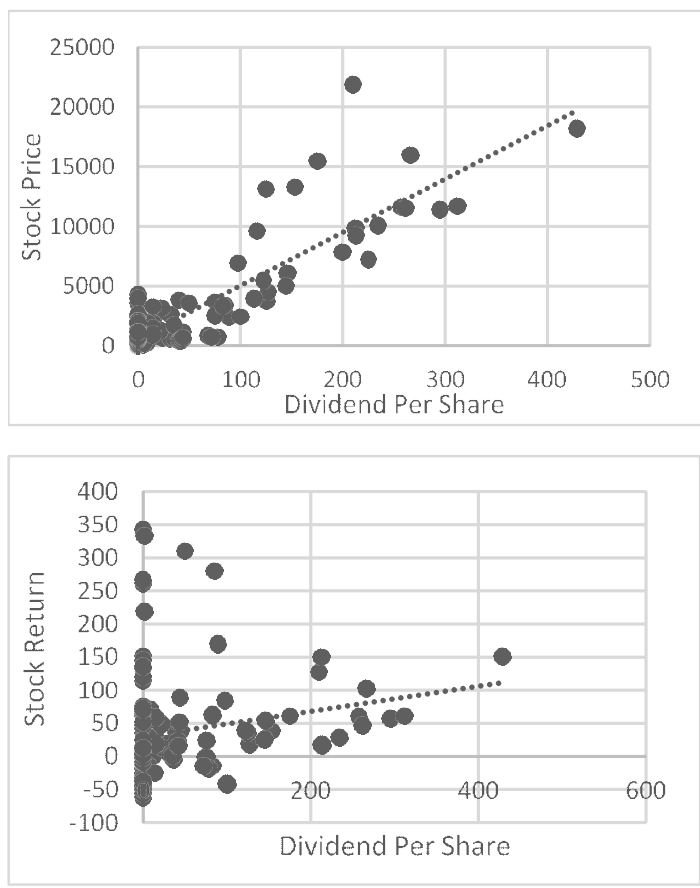

Figure 6. The relationship of dividends per share with stock prices and stock returns

Table 1. Description of stock price and its internal factors based on the BUKU banking sub-sectors in 2013-2017

\begin{tabular}{|c|c|c|c|c|}
\hline & $\begin{array}{c}\text { Bank BUKU } \\
1 \\
\end{array}$ & $\begin{array}{c}\text { Bank BUKU } \\
2 \\
\end{array}$ & $\begin{array}{c}\text { Bank BUKU } \\
3 \\
\end{array}$ & $\begin{array}{c}\text { Bank BUKU } \\
4 \\
\end{array}$ \\
\hline Number of banks & 2 & 13 & 12 & 4 \\
\hline Number of banks that provide dividends & 0 & 6 & 9 & 4 \\
\hline Percentage of banks that give dividends (\%) & 0 & 46 & 75 & 100 \\
\hline Maximum dividend value (IDR) & 0 & 40 & 126.5 & 428.61 \\
\hline Minimum dividend value (IDR) & 0 & 0 & 0 & 113.35 \\
\hline Stock price (IDR) & 880.4 & 835.2 & 1614.67 & 9901.25 \\
\hline Dividends per Share (IDR) & 0 & 3.72 & 29.27 & 222.18 \\
\hline Dividen Payout Ratio (IDR) & 0 & 6.40 & 16.32 & 36.47 \\
\hline Dividend Growth (IDR) & 0 & 8.86 & 16.28 & 14.67 \\
\hline NPL (\%) & 6.31 & 3.02 & 2.85 & 2.08 \\
\hline NIM (\%) & 5.55 & 4.12 & 5.99 & 8.10 \\
\hline
\end{tabular}



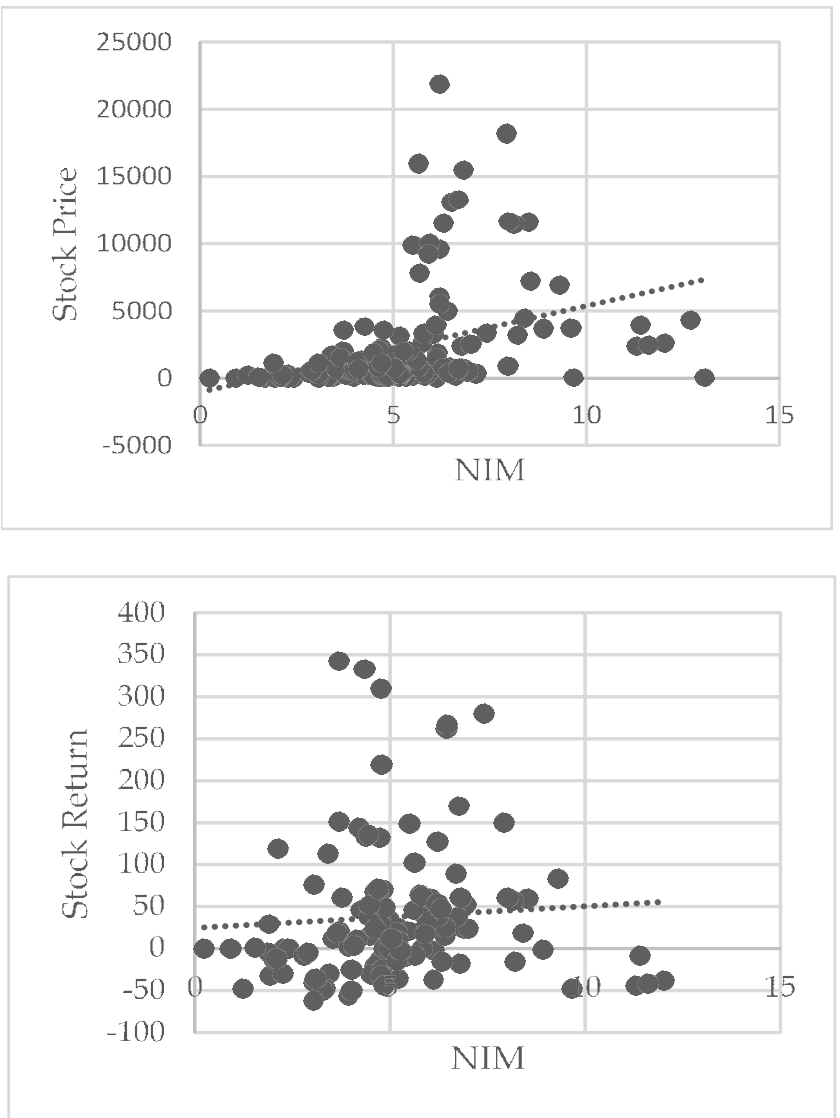

Figure 7. The relationship of Net Interest Margin (NIM) with stock prices and stock returns

External factors that influence stock prices of banking subsector is Rupiah Exchange Rate (REER), Inflation rate and Interest rates. In Indonesia, REER has increased by 9.94 percent for five years. From 2013 to 2018, inflation in Indonesia has decreased significantly. In 2015, inflation decreased by 59.93 percent and apparently steady in 2016 and 2017. The decrease in inflation in 2015 was triggered by a decline of approximately 50 percent of world oil prices in mid-2014. The decline in world oil prices leads to a decrease in fuel oil prices and the decline in the prices of other goods and services. The interest rate had a large decrease of 36.67 percent in 2016. The decline in the interest rate led to a decline in the inflation of the previous year. In 2015, inflation fell off by 59.93 percent.

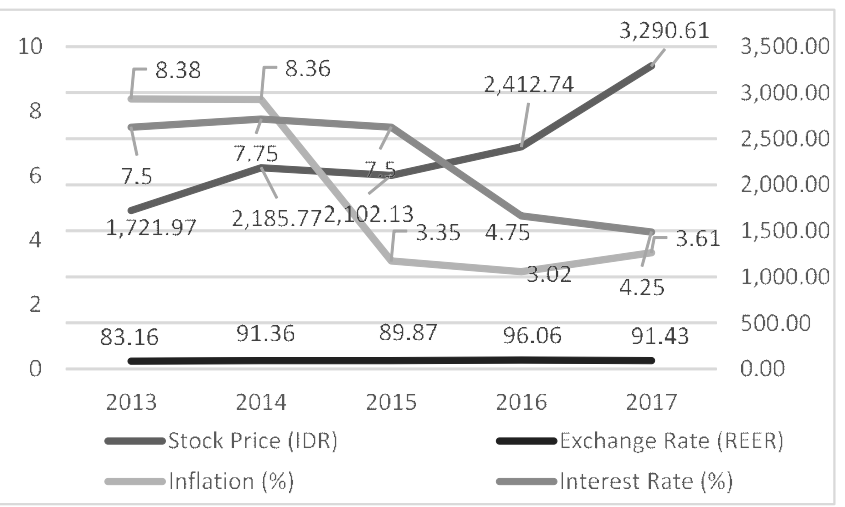

Figure 8. Average stock price of banking subsector, exchange rate (REER), inflation and interest rate for the period of 2013-2017

The panel data regression model uses three model approaches i.e., Pooled Least Square (PLS) or Common Effect, Fixed Effect Model (FEM), and Random Effect Model (REM). A Chow test is carried out to determine the best model between Pooled Least Square (PLS) and Fixed Effect Model (FEM). Based on the Chow Test result, FEM is the best model. Furthermore, the next test to determine the best model between FEM and REM is the Hausman Test. The result of the test indicates that FEM is the best model. In addition, the Lagrange Multiplier (LM) test is not carried out because the previous two tests are sufficient to estimate the best model, that is the Fixed Effect Model (FEM).

The study uses a classical assumption test i.e., normality test, heteroscedasticity test, autocorrelation test, and multicollinearity test. Based on the classic assumption test, the model is declared free from any classical assumption problems. In order to confirm that there is no correlation between variables, a VIF (Variance Inflation Factor) test is performed. The centered value of VIF is $<10$, meaning that there is no multicollinearity between independent variables.

The results of the panel data regression test show that dividends, NIM, and interest rates have a significant effect on the stock price of the banking subsector (Table 2) 
The results of the OLS test using the dummy variable of the book reveals that dividend, NIM, and NPL have significant effects on stock prices (Table 3). From dummy variables on BUKU 1, BUKU 2 , and BUKU 3, These all three are significantly different from BUKU 4 with the magnitude of influence for dummy BUKU 1 amounting to -1.7959 , which means book stock price 1 is lower by 1.7959 percent compared to BUKU 4. A big influence for BUKU 2 dummy is -2.1381 means price BUKU 2 shares lower 2.1381 percent compared to BUKU 4. By the same token, the effect for BUKU 3 dummy amounts to -1.0214 , meaning that stock prices of BUKU 3 are 1.0214 percent lower than BUKU 4.

Table 2. Results of panel data regression

\begin{tabular}{lcccc}
\hline Variable & Coefficient & Std Error & t-Statistic & Prob. \\
\hline Dividend & 0.003079 & 0.000552 & 5.581010 & $0.0000^{* *}$ \\
NPL & -0.005439 & 0.011315 & -0.480679 & 0.6316 \\
NIM & 0.038424 & 0.015692 & 2.448622 & $0.0158^{*}$ \\
Inflasi & 0.004346 & 0.006184 & 0.702806 & 0.7028 \\
Interest Rate & -0.063094 & 0.020297 & -3.108633 & $0.0024^{* *}$ \\
Rupiah Exchange Rate (REER) & 0.786012 & 0.516871 & 1.520713 & 0.1310 \\
C & 3.160627 & 2.446384 & 1.291958 \\
\hline R-squared & 0.965568 & & & \\
F-statistic & 91.91855 & & & \\
Prob(F-statistic) & 0.000000 & & &
\end{tabular}

Table 3. A result of OLS Regression (with dummy BUKU variables)

\begin{tabular}{lrcrr}
\hline \multicolumn{1}{c}{ Variable } & Coefficient & Std. Error & t-Statistic & Prob. \\
\hline DEV & 0.005407 & 0.002351 & 2.299911 & $0.0229^{*}$ \\
NPL & -0.087688 & 0.041164 & -2.130225 & $0.0348^{*}$ \\
NIM & 0.111776 & 0.044858 & 2.491776 & $0.0138^{*}$ \\
INF & -0.001578 & 0.047981 & -0.032890 & 0.9738 \\
SB & -0.062912 & 0.075143 & -0.837228 & 0.4038 \\
KURS & 1.597150 & 2.322598 & 0.687657 & 0.4928 \\
Dummy_BUKU1 & -1.795951 & 0.648652 & -2.768742 & $0.0064^{*}$ \\
Dummy_BUKU2 & -2.138113 & 0.532509 & -4.015169 & $0.0001^{*}$ \\
Dummy_BUKU3 & -1.021412 & 0.493591 & -2.069347 & $0.0403^{*}$ \\
C & 0.716222 & 10.71497 & 0.066843 & 0.9468 \\
\hline R-squared & 0.636849 & Mean dependent var & & 6.631647 \\
Adjusted R-squared & 0.614309 & S.D. dependent var & & 1.598983 \\
S.E. of regression & 0.993033 & Akaike info criterion & & 2.886235 \\
Sum squared resid & 142.9866 & Schwarz criterion & & 3.082585 \\
Log-likelihood & -213.6832 & Hannan-Quinn criteria. & & 2.965988 \\
F-statistic & 28.25368 & Durbin-Watson stat & & 0.610006 \\
Prob(F-statistic) & 0.000000 & & & \\
\hline
\end{tabular}

Note: ${ }^{*}$ ) significant at level $5 \%$ 


\section{Dividend payout, internal and other external factors, and its impact on stock price}

Tribella Kembaren, Noer Azam Achsani, Tb Nur Abmad Maulana

\section{Discussion}

Dividends of bank BUKU 4 is higher than dividends of the bank BUKU 1, 2, and 3. Based on the results of the OLS test with book dummy variables, the stock prices of the bank have varied significantly from each other. The result is similar to a study by Kurniasih (2011) that companies issuing dividend payouts are those with large size. Anas (2010) stated that one of several factors affecting the provision of dividends is the size of the company. In Figure 6, there is a linear relationship between dividend with stock prices \& stock returns. The results of panel data regression testing and OLS regression testing (with a dummy variable) show that the dividend has a significant positive influence on stock prices of banking sub-sector. Investors take the provision of dividends to identify recent profits as well as to predict future profits of companies. The research findings are similar to the theory of bird on the hand by Lintner (1962) and Gordon (1963) which suggests that investors prefer dividends as they serve definite incomes. Another similar study is from Badruzaman \& Kusmayadi (2017), dividend payout ratio significantly influences stock prices on 35 public companies enlisted in LQ45 index of the Indonesia Stock Exchange. According to Deni, Aisjah, \& Ajazuli (2016), dividend policy is implemented by companies to allow investors to predict good profitability of companies in the future.

Based on panel data regression and OLS regression (dummy variable), NIM has a significant positive influence on stock prices of banking subsector. In figure 7, there is a positive linear relationship between NIM with stock prices and stock returns. Net Interest Margin (NIM) represents the amount of net interest earned by a bank. It is associated with the number of profits earned by the bank. The higher the NIM, the higher the bank's profit. The increase in NIM indicates an increase in profits of banks and regarded as a good signal for investors. It is similar to a study by Raharjo (2013),
NIM has a significant positive influence on bank performance (measured through ROA). Harahap \& Hairunnisah (2017) found that NIM has a positive and significant influence on stock prices of banking companies on the IDX. Based on the results of the panel interest rate regression, the interest rate has a significant and negative influence on the stock price of the banking sub-sector. When the interest rate increases, people tend to deposit money in banks and to withdraw funds from the stock exchange. This condition can reduce stock prices. Meanwhile, high-interest rates encourage people to reduce loans of banks. The bank must pay deposit interests or higher deposits. It reduces bank profits. The results of the study are in line with Shivaani, Yadav, \& Jain (2015), there is a negative and significant relationship between interest rates and stock prices. The bank must pay either interest on deposits or higher amount of deposits. As a result, it reduces the profit of the bank. On the other hand, when interest rates decline, investors tend to divert their investment from bank deposits to stocks market. During this research period, interest rates decline from the period of 2015-2017, leading to an increase in stock prices of banking sub-sector in the same year period. The interest rates decreased by 36.66 percent in the 2015-2016 period and were followed by an increase in the stock prices of the banking subsector by 14.77 percent. In the period of 2016-2017, interest rates decreased by 10.5 percent and the stock price of the banking subsector increased by 36.4 percent. In addition, the OLS test (dummy variable) indicates that interest rate negatively affects stock prices with no significant effect. It is due to different interest rate policies of each group of the bank which can be observed from NIM by each bank. The bank BUKU 1,2 and 3 earn NIM are lower than the bank BUKU 4.

Based on the OLS test using dummy variables, NPL has a significant negative effect on stock prices. If NPL is high, bank profit will decrease. This is an alert for investors since the magnitude subsequently leads to a decline in the stock price of the banking sub-sector. Moreover, Partovi \& Matousek 
(2018) states that NPL brings negative impact on technical efficiency and poor hypothesis of management in the banking sector. The panel data regression test illustrates the negative but non-significant relationship between NPL and stock prices.

\section{Conclusions, Limitations, and Suggestions Conclusion}

Based on the research findings, not every company in the banking sub-sector does provide annual dividends. Companies in BUKU 4 provide dividends every year and have a higher Dividend Yield and Dividend Payout Ratio than bank BUKU 1,2 and 3. Banks with higher core capital provides higher Dividend Yield and higher Dividend Payout Ratio. The panel data regression shows that some factors significantly influence the banking stock prices for a period of 2013-201, these are Dividend (DIV), Net Interest Margin (NIM) and Interest Rate. In addition, the results of OLS regression test (dummy variable) show that Dividend (DIV), Net Interest Margin (NIM) and Non Performing Loans (NPL) have a significant effect on the banking stock prices.

The findings of this study can be used as a reference for corporate banking subsector to con- sider the impacts of dividend policy and management of Net Interest Margin (NIM) and Non-Performing Loans (NPLs) because these factors have an influence on stock prices of corporate banking subsector. The findings of this study can be used as a benchmark and reference for any investors. Investors who prefer dividends may choose stocks of bank BUKU 4, which consistently provide annual dividends with higher dividend yield and dividend payout ratio than other BUKU. In addition, investors must consider the dividend policies and NIM of banks because both factors have a significant positive effect on the stock price. If both factors increase, the stock prices will increase as well.

\section{Limitations and suggestions}

Furthermore, this study has limitations. It uses panel data regression that is incapable to distinguish each category of BUKU. The OLS regression test uses BUKU as a dummy variable as well. Therefore, for further study, it is recommended to use testings that differentiate each category of BUKU. Moreover, this study only focuses on the banking subsector which suggests a comparison of subsectors/sectors in the future studies to get more comprehensive results.

\section{References}

Anas, M. (2012) Analisis faktor-faktor yang mempengaruhi kebijakan dividen pada perusahaan yang terdaftar di Bursa Efek Indonesia. Tesis. Universitas Sebelas Maret

Badruzaman, J., \& Kusmayadia, D. (2017) Dividend Payout Ratio influence towards stock price (Survey of the firm LQ 45 listed in Indonesian Stock Exchange). Advanced Science Letters, 23(9), 8793-8795. https://doi.org/10.1166/asl.2017.9972

Baker, M., \& Wurgler, J. (2004) A catering theory of dividend. Journal of Finance, 59(3), 1125-1165. https://doi.org/10.1111/j.1540-6261.2004.00658.x

Bank Indonesia. (2012). Peraturan Bank Indonesia Nomor 14/26/PBI/2012 tentang kegiatan usaha dan jaringan kantor berdasarkan modal inti bank. Jakarta (ID): Bank Indonesia

Clark-Murphy, M., \& Soutar, G. N. (2004) What individual investors value: Some Australian evidence. Journal of Economic Psychology, 25(4), 539-555. https://doi.org/10.1016/S0167-4870(03)00056-4 


\section{Dividend payout, internal and other external factors, and its impact on stock price}

Tribella Kembaren, Noer Azam Achsani, Tb Nur Ahmad Maulana

Deni, F. F., Aisjah, S., \& Ajazuli A. (2016) Analisis variabel-variabel yang mempengaruhi kebijakan dividen (Studi pada perusahaan manufaktur yang terdaftar di Bursa Efek Indonesia). Jurnal Aplikasi Manajemen, 14(2), 359-365. http://dx.doi.org/10.18202/jam23026332.14.2.17

Gordon, M. J. (1963). Optimal investment and financing policy. Journal of Finance, 18(2), 264-272. https://doi.org/10.1111/j.1540-6261.1963.tb00722.x

Lintner, J. (1962). Dividends, earnings, leverage, stock prices and supply of capital to corporations. The Review of Economics and Statistics, 64(3), 243-269. https://doi.org/10.2307/1926397

Harahap D. A., \& Hairunnisah, A. I. (2017). Pengaruh NPL, LDR, GCG, NIM, ROA, ROE, CAR, BOPO, terhadap harga saham pada perusahaan perbankan yang terdaftar di Bursa Efek Indonedia dari tahun 2010-2014. Jurnal Dimensi, 6(1), 22-40.

Hashemijoo M., Ardekani, A. M., \& Younesi N. (2012). The impact of dividend policy on share price volatility in the Malaysian Stock Market. Journal of Business Studies Quarterly, 4(1), 111-129.

Hughen, J. C., \& Beyer, S. (2015). Stock returns and the US dollar: The importance of monetary policy. Managerial Finance, 41(10), 1046-1058. https://doi.org/10.1108/MF-09-2014-0234

Kurniasih A. (2011). Analisis karakteristik perilaku, faktor penentu dan reaksi pasar terhadap kebijakan dividen perusahaan tercatat di Bursa Efek Indonesia. Disertasi. Institut Pertanian Bogor.

Miller, M. H., \& Modigliani F. (1961). Dividend policy, growth and the valuation of shares. Journal of Business, 34(4), 411-433. https://doi.org/10.1086/294442

Otoritas Jasa Keuangan. (2015). Potensi pertumbuhan ekonomi ditinjau dari penyaluran kredit perbankan kepada sektor prioritas ekonomi pemerintah. Departemen Pengembangan Pengawasan dan Manajemen Krisis. Divisi Analisis Profil Industri. Jakarta.

Otoritas Jasa Keuangan. (2016). POJK Nomor 6/POJK.03/2016 Tentang Kegiatan Usaha dan Jaringan Kantor Berdasarkan Modal Inti Bank. Jakarta.

Partovi, E., \& Matousek, R. (2018). Bank efficiency and non-performing loans: Evidence from Turkey. Research in International Business and Finance, 48, 287-309. https://doi.org/10.1016/j.ribaf.2018.12.011

Raharjo, D. P. A. (2013) Analisis pengaruh Rasio CAR, NPL, LDR, BOPO, dan NIM terhadap kinerja bank umum di Indonesia periode 2010-2011. Tesis. Universitas Muhammadiyah Surakarta.

Shivaani, M. V., Yadav, S. S., \& Jain, P. K. (2015). Market risk exposure: Evidence from Indian Banking Industry. IUP Journal of Applied Finance, 21(3), 80-87.

Sutrisno. (2001), Manajemen Keuangan Teori, Konsep, dan Aplikasi, Yogyakarta (ID): Ekonisia

Wijayanti. (2010) Analisis kinerja keuangan dan harga saham perbankan di Bursa Efek Indonesia (BEI). Journal of Indonesian Applied Economics, 4(1), 71-80 